\title{
Protein Haemaglutinin Outer Membran Protein (OMP) 35 kDa sebagai Protein Adhesin Proteus mirabilis pada Vesika Urinaria Kelinci
}

\author{
Enny Suswati*) dan Diana Chusna Mufida \\ Laboratorium Mikrobiologi Fakultas Kedokteran Universitas Negeri Jember \\ JL. Kalimantan 37 Jember \\ Diterima 26-06-2009 Disetujui 25-11-2009
}

\begin{abstract}
Proteus mirabilis is opportunistic and nosocomial pathogen that usually found in clinical specimen from patients with catheter. The pathogenic mechanism of the bacteria are not fully elucidated especially its potential activity of the protein as hemaglutinin and adhesion molecule. The aim of this study is to evaluate the role of $35 \mathrm{kDa}$ outer membrane protein from P. mirabilis. After identification, bacterial isolate of OMP fraction $12,5 \%$ SDS-PAGE were used to isolate OMP followed by hemaglutinin test and invitro adhesion test. The study showed that the $35 \mathrm{kDa}$ OMP of $P$. mirabilis was a hemaglutinin protein that could agglutinate mice erythrocytes, rabbit erythrocytes, and human group $O$ erythrocytes. Hemaglutination test were negative on erythrocytes human blood group $A, B$, and $A B$. The 35 $\mathrm{kDa}$ OMP was also adhesion protein showed by its activity to adhere to the rabbit vesica urinaria epithel receptor. The increase dose of $35 \mathrm{kDa}$ OMP will decrease the amount of $P$. mirabilis bacteria to adhere to rabbit vesica urinaria epithel $(p<0,05)$.
\end{abstract}

Keywords: adhesion protein, fimbriae, hemaglutinin protein, Proteus mirabilis

\section{PENDAHULUAN}

Penyakit infeksi merupakan penyakit yang banyak diderita masyarakat Indonesia sejak dulu, diantaranya adalah infeksi saluran kemih (ISK). ISK merupakan keadaan tumbuh dan berkembang biaknya kuman dalam saluran kemih, meliputi infeksi di parenkim ginjal sampai infeksi di vesika urinaria dengan jumlah bakteriuria yang bermakna (Slayer \& Whitt, 2002).

Proteus mirabilis merupakan salah satu penyebab terpenting ISK. ISK yang disebabkan oleh bakteri ini bersifat persisten, sulit diterapi, dan dapat berakibat fatal. $P$ mirabilis menghasilkan urease yang memecah urea menjadi ammonia dan karbondioksida yang akan meningkatkan $\mathrm{pH}$ urin. $\mathrm{pH}$ yang meningkat maka presipitasi komponen urin $\left(\mathrm{Ca}^{2+}\right.$ dan $\left.\mathrm{Mg}^{2+}\right)$ menjadi lebih mudah sehingga menimbulkan terbentuknya batu. Adanya batu baik di vesika urinaria dan ginjal menyebabkan infeksi saluran kemih menjadi persisten dan rekuren. Selain itu dengan adanya batu dan infeksi secara bersamaan akan mengakibatkan kerusakan ginjal, baik akut maupun kronik pyelonephritis dan juga dapat menimbulkan bakteremia (Perepelov et al., 1999; Wassif et al., 1995). Disamping itu $P$ mirabilis dapat invasi ke sel epitel dan menetap

\footnotetext{
*Telp: +62331337877

Email: enny_suswati@yahoo.com
}

di dalam sel epitel, menyebabkan bakteri ini menjadi sulit diterapi dengan beberapa jenis antibiotika seperti cotrimoksasol, amoksisilin-asam clavulonat, nitrofurantoin dan siprofloksasin (Mathoera et al., 2002).

Patogenesis bakteri untuk menimbulkan suatu penyakit, secara umum ada dua tahap. Pada tahap pertama bakteri akan melakukan pelekatan ke sel inang, pada pelekatan awal diperankan oleh pili dan sifat pelekatannya adalah anchoring, setelah itu dilanjutkan dengan pelekatan melalui outer membrane sel, yang pelekatannya bersifat doching. Setelah melakukan pelekatan maka bakteri akan berkembang biak disertai dengan produksi bahan-bahan metabolisme bakteri yang dapat merugikan sel inang (Salyer \& Whitt 2002).

Molekul adhesin merupakan salah satu faktor virulensi bakteri dan pada beberapa bakteri protein hemaglutinin berfungsi pula sebagai protein adhesion (Salyer \& Whitt 2002; Noorhamdani 2005). Berat molekul adhesin bervariasi antara satu bakteri dengan bakteri yang lainnya. Acinobacter baumanni mempunyai molekul hemaglutinin dan juga merupakan molekul adhesin (Noorhamdani 2005). Demikian juga pada bakteri Salmonella typhi mempunyai molekul hemaglutinin yang juga berperan sebagai adhesin, yaitu protein pili dengan berat molekul $36 \mathrm{kDa}$ (Sanarto 
2002). Tujuan penelitian ini adalah untuk membuktikan bahwa Outer Membrane Protein P. mirabilis merupakan protein hemaglutinin yang berfungsi sebagai adhesin, dengan berat molekul $35 \mathrm{kDa}$.

\section{BAHAN DAN METODE}

Identifikasi $\boldsymbol{P}$. Mirabilis. Spesimen secara aseptic ditanam pada medium agar Mac Conkey dan diinkubasi pada suhu $37^{\circ} \mathrm{C}, 18-24$ jam. Koloni yang tumbuh dibuat pewarnaan Gram dan dilihat di bawah mikroskop. Identifikasi bakteri dilakukan dengan pemeriksaan mikroskopis yaitu bakteri bentuk batang atau kokobasil. Jika dikultur pada media agar akan tampak fenomena swarming. Uji phenilalanin+, urease+, $\mathrm{H}_{2} \mathrm{~S}+$, ornithin+, indole-, fermentasi adonitol-, inositol-.

Subkultur $\boldsymbol{P}$. Mirabilis. Bakteri yang akan digunakan adalah $P$ mirabilis galur lokal yang berasal dari urin pasien bakteriuria. Metode yang digunakan menurut petunjuk Ehara et al., (1992), yaitu media TCG yang memperkaya pertumbuhan pili $P$ mirabilis. Media ini megandung 0,02\% thioproline, 0,3\% NaHCO3, 0,15 bactotrytonr, $0,2 \%$ yeast extract, $0,5 \% \mathrm{NaCl}, 2 \%$ bacto agar dan $1 \mathrm{mM}$ EGTA. Media agar dibuat dalam botol kapasitas $250 \mathrm{ml}$ secara miring sebanyak $50 \mathrm{ml}$ agar. $P$ mirabilis yang ditanam pada media Brain Heart Infusion (BHI) yang diinkubasi pada suhu $37^{\circ} \mathrm{C}$ selama 4 jam. Kemudian suspensi bakteri sebanyak $10 \mathrm{ml}$ dimasukkan dalam setiap botol yang mengandung media TCG. Selanjutnya dilakukan inkubasi pada suhu $37^{\circ} \mathrm{C}$ selama $2 \times 24$ jam.

Isolasi OMP P. Mirabilis. Isolasi OMP $P$, mirabilis dilakukan dengan modifikasi Evans, sampel diambil dari endapan terakhir isolasi pilih yang warnanya medekati warna PBS, pelet disuspensikan dengan PBS pH 7,4 sampai volumeya sampai 15 kali kemudian ditambahkan (NOG) n-octyl B-Dglucopyranoside dengan konsentrasi 0,5\%. Dihomogenkan dengan vortex menggunakan kecepatan penuh selama 1 menit. kemudian di setrifugasi dengan kecepatan $12.000 \mathrm{rpm}$ suhu $4^{\circ} \mathrm{C}$ selama 30 menit. Cairan supernatan diambil dan dilakukan dialisa Cairan dialisis pada 24 jam pertama digunakan $\mathrm{d}_{2} \mathrm{O}$ dan pada 24 jam kedua dipakai PBS pH 7,4 dilakukan sampai 6 kali.

Sodium Dodecyl Sulfate Polyacrilamide Gel Electroforesis (SDS-PAGE). Monitoring berat molekul dikerjakan menggunakan SDS-PAGE (Smeds et al., 2001). Sampel protein dipanaskan $100^{\circ} \mathrm{C}$ selama 5 menit dalam larutan penyangga yang mengandung $5 \mathrm{mM}$ Tris $\mathrm{HCl} \mathrm{pH} \mathrm{6,8,} \mathrm{2-} \mathrm{mercapto} \mathrm{ethanol} \mathrm{5 \% ,} \mathrm{w/v} \mathrm{sodium} \mathrm{dodecyl}$ sulfate $2,5 \%$, v/v gliserol $10 \%$ dengan warna pelacak bromophenol blue. Dipilih mini slab gel 12,5\% dengan tracking gel $4 \%$. Voltase yang digunakan $125 \mathrm{mV}$. Bahan yang digunakan adalah coomasive brilliant blue dan molekul standart sigma low range marker.

Pemurnian Fraksi Protein OMP. Metode yang dilakukan seperti yang telah dikerjakan oleh Ehara dengan modifikasi (Sumarno 2000). Hasil SDS-PAGE koleksi fimbria gel, gelnya dipotong lurus pada bobot molekul yang diinginkan dan potongan pita tersebut dikumpulkan dan dimasukkan dalam membran dialisis memakai cairan penyangga elektroforesis, running buffer. Selanjutnya dilakukan elektroelusi menggunakan elektroforesis frontal apparatus aliran 125 mv selama 25 menit. Hasil elektroforesis dilakukan dialisis dengan cairan penyangga PBS pH 7,4 selama 2x24 jam @ 1 liter dan diganti dua kali. Cairan dialisat tersebut dilakukan uji hemaglutinasi.

Uji Hemaglutinasi. Uji hemaglutinasi dikerjakan menurut petunjuk dari Li (1999). Pengenceran sampel dibuat konsentrasi I/2 pada mikroplat $V$, dimana tiap sumur volumenya $50 \mu \mathrm{l}$. Tiap sumur ditambahkan suspensi darah merah mencit konsentrasi $0,5 \%$ volume sama. Kemudian digoyang dengan rotator plate selama 1 menit. Selanjutnya diletakkan dalam suhu kamar selama 1 jam. Besarnya titer ditentukan dengan pengamatan adanya agglutinasi darah merah pada pengenceran yang terendah. Sampel yang diuji adalah crude pili ,protein pili, protein Omp Proteus mirabilis. Darah yang dipakai adalah darah mencit, kelinci dan manusia.

Isolasi Sel Epitel Vesica Urinaria Kelinci. Isolasi sel epitel vesika urinaria kelinci dilakukan menurut metode Weisser (Nagayama et al.,1995). Kelinci yang dipakai adalah kelinci yang sehat dengan kira-kira 1,5 kg. Kelinci dianestesi dengan menggunakan kloroform, kemudian diambil bagian vesika urinaria dipotong dan dibuka. Vesica urinaria dicuci dengan $\mathrm{PBS} \mathrm{pH} \mathrm{7,4} \mathrm{yang} \mathrm{mengandung} 1 \mathrm{mM}$ dithiothretiol pada suhu $4^{\circ} \mathrm{C}$ sampai tampak bersih. Setelah itu vesica urinaria dimasukkan dalam cairan yang mengandung 1.5mM KCl, 9.6 mMNaCl, $27 \mathrm{mMNa}$ Citrat, $8 \mathrm{mM} \mathrm{KH}_{2} \mathrm{SO}_{4}$ dan 5,6 mM Na $2 \mathrm{HPO} 4$ dengan $\mathrm{pH} 7,4$, selanjutnya jaringan diinkubasi pada shaking incubator selama 15 menit, dengan suhu $37^{\circ} \mathrm{C}$. Supernatan dibuang dan jaringan dipindahkan dalam cairan yang mengandung 1,5 mM EDTA dan 0,5 mM 
dithiothretiol. Selanjutnya jaringan yang berada dalam cairan yang mengandung EDTA dan dithiotretiol digojok kuat selama 15 menit pada suhu $37^{\circ} \mathrm{C}$, kemudian supernatant dibuang. Jaringan dicuci dengan PBS dan disentrifugasi selama 5 menit dengan kecepatan 1000 rpm, dan diulang sebanyak tiga kali. Epitel vesica urinaria diisolasi dengan melakukan suspensi pada jaringan dengan menggunakan PBS steril dan selanjutnya dianalisis dengan spektrofotometer pada panjang gelombang $560 \mathrm{~nm}$ sampai konsentrasi $10^{6} / \mathrm{ml}$. Epitel vesika urinaria ini siap untuk dilakukan uji adhesi .

Uji Adhesi. Uji adhesi modifikasi Nagayama et al., (1995), pada uji adhesi bakteri P. mirabilis dibiakkan dalam laktosa broth pada suhu. Selanjutnya bakteri dipanen dengan menggunakan sentrifugasi $6000 \mathrm{rpm}$ selama 10 menit pada suhu $4^{\circ} \mathrm{C}$. Endapan disuspensi dengan PBS dan kandungan bakteri dibuat $10^{8} / \mathrm{ml}$ dengan menggunakan spektrofotometer pada panjang gelombang $600 \mathrm{~nm}$.

Selanjutnya dibuat preparasi dosis protein fimbria masingmasin-g sebanyak $0 \mu \mathrm{l}$ (kontol), $25 \mu \mathrm{l}, 50 \mu \mathrm{l}$, $100 \mu \mathrm{l}, 200 \mu \mathrm{l}, 400 \mu \mathrm{l}$ dan 800 ul dalam $300 \mu \mathrm{l}$ PBS. Pada masing-masing dosis ditambahkan suspensi epitel sebanyak $300 \mu \mathrm{l}$ dan digoyang perlahan pada shaking waterbath pada suhu $37^{\circ} \mathrm{C}$, selama 30 menit.

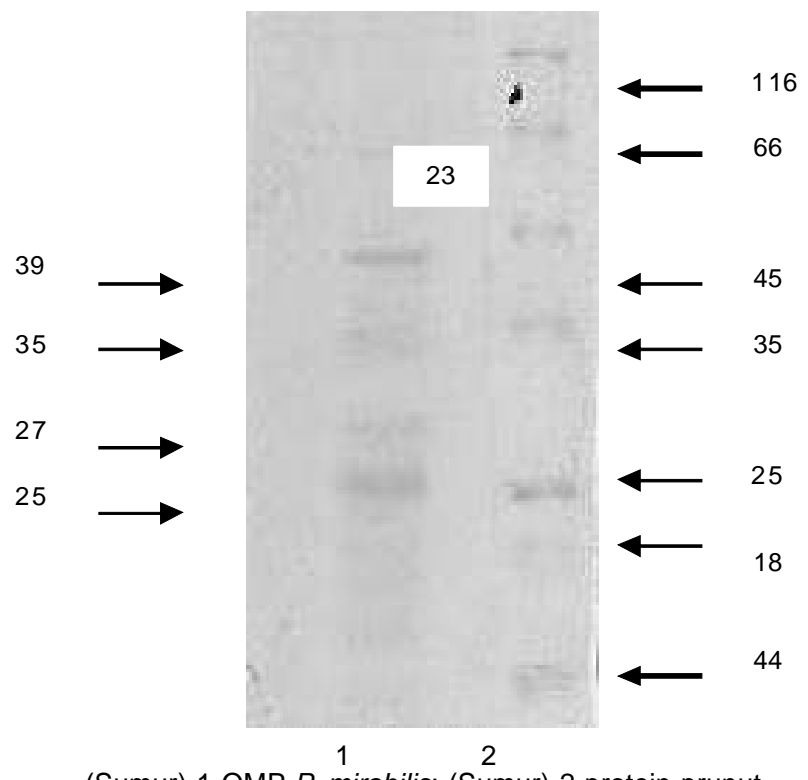
Gambar 1. Hasil SDS-PAGE Potongan OMP P. mirabilis
Kemudian ke dalam setiap campuran tersebut ditambah suspensi bakteri sebanyak $300 \mu$ l. Campuran diinkubasi dengan shaking inkubator selama 30 menit pada suhu $37^{\circ} \mathrm{C}$. Selanjutnya disentrifugasi $1500 \mathrm{rpm}$ pada suhu $4^{\circ} \mathrm{C}$ selama 3 menit, kemudian endapan dicuci dua kali dengan PBS. Endapan diambil dan dibuat hapusan pada gelas obyek dan dicat dengan pewarnaan Gram. Preparat diamati dengan mikroskop pembesaran 1000 kali dan dihitung jumlah bakteri yang menempel pada sel epitel. Indeks adhesi adalah jumlah rerata bakteri yang menempal pada epitel, dihitung untuk setiap pengamatan terhadap 100 epitel ( Martino et al., 1995).

Analisis Statistik. Menggunakan ANOVA dan uji regresi, dengan batas signifikan 0,05.

\section{HASIL DAN PEMBAHASAN}

Bakteri $P$. mirabilis diambil dari pasien infeksi saluran kemih di rumah sakit. Bakteri yang telah diidentifikasi tersebut dikultur pada media bifasik, TCG$\mathrm{BHI}$ untuk memperkaya pertumbuhan pili. Setelah 48 jam bakteri tersebut dipanen dan dilakukan pemotongan pili secara bertingkat, sampai warna supernatan dari pili sama dengan warna PBS dan endapan terakhir dari pemotongan pili di beri NOG sampai kadar 0,05\%. Selanjutnya supernatan bakteri OMP didialisis selama $2 \times 24$ jam dengan menggunakan PBS.

Uji Hemaglutinasi. Selanjutnya hasil potongan pili dan OMP tersebut dilakukan uji hemaglutinasi dengan menggunakan eritrosit mencit, yang bertujuan untuk melihat pili dan OMP potongan mana yang mengandung protein hemaglutinin. Hasil uji hemaglutinin terdapat pada Tabel 1.

Hasil uji hemaglutinasi ini menunjukkan bahwa OMP dengan titer $1 / 512$ merupakan titer tertinggi. Selanjutnya OMP dilakukan SDS-PAGE untuk memprediksi berat molekul protein, dengan hasil seperti Gambar 1.

Hasil protein pada SDS-PAGE dari potongan OMP $P$. mirabilis menunjukkn ada beberapa protein yang menonjol yaitu protein dengan berat molekul $39 \mathrm{kDa}$, $35 \mathrm{kDa}, 27 \mathrm{kDa}$ dan $25 \mathrm{kDa}$. Pada penelitian ini dilakukan uji pada potongan OMP dengan berat molekul $35 \mathrm{kDa}$. Selanjutnya protein dengan berat molekul $35 \mathrm{kDa}$ tersebut di potong dan dilakukan elektroelusi

Tabel 1. Uji hemaglutinasi pili dan OMP P. mirabilis pada eritrosit mencit

\begin{tabular}{|c|c|c|c|c|c|c|c|c|c|c|}
\hline \multirow[b]{2}{*}{ Materi } & \multicolumn{10}{|c|}{ Pengenceran } \\
\hline & $1 / 2$ & $1 / 4$ & $1 / 8$ & $1 / 16$ & $1 / 32$ & $1 / 64$ & $1 / 128$ & $1 / 1256$ & $1 / 512$ & 0 \\
\hline OMP & + & + & + & + & + & + & + & + & + & - \\
\hline
\end{tabular}


haemglutinasi pada berbagai eritrosit dengan hasil seperti pada Tabel 2.

Uji Hambat Adhesi. Uji hambat adhesi P. mirabilis dilakukan secara invitro pada sel epitel vesika urinaria kelinci, menggunakan protein hemaglutinin OMP dengan berat molekul $35 \mathrm{kDa}$ diberikan dosis bertingkat, mulai dari $400 \mu \mathrm{l}$ sampai $12,5 \mu \mathrm{l}$ dan dosis $0 \mu \mathrm{l}$ sebagai kontrol. Gambaran epitel vesika urinaria yang telah dilakukan pengecatan gram adalah tampak pada Gambar 2.

Hasil uji hambat adhesi $P$. mirabilis pada sel epitel vesika urinaria, dilakukan dimulai dengan dosis protein hemaglutinin $0 \mu \mathrm{l}$ sebagai kontrol tampak pada Gambar 3 dan dilanjutkan dengan dosis terbesar protein OMP hemaglutinin sampai dosis terkecil tampak pada Gambar 4.

Keterlibatan protein hemaglutinin dengan berat molekul $35 \mathrm{kDa}$ dalam menghambat perlekatan $P$. mirabilis terlihat pada (gambar 4). Sedikitnya perlekatan bakteri pada sel epitel vesika urinaria setelah diinkubasi dengan protein hemaglutinin menunjukkan bahwa

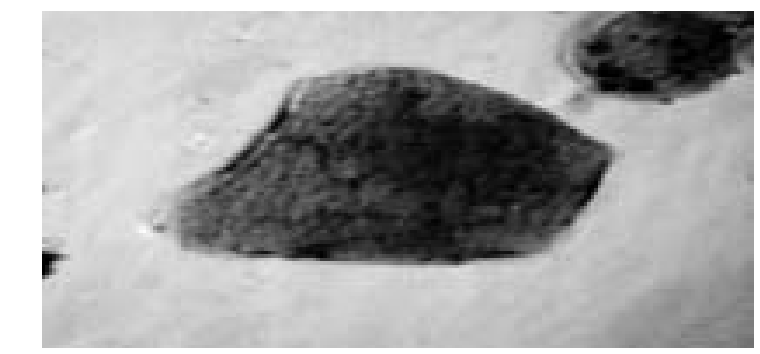

Gambar 2. Epitel Vesika Urinaria Kelinci dengan Pengecatan Gram Direkam dengan Fotomikroskop Olympus dengan Perbesaran 1000 kali

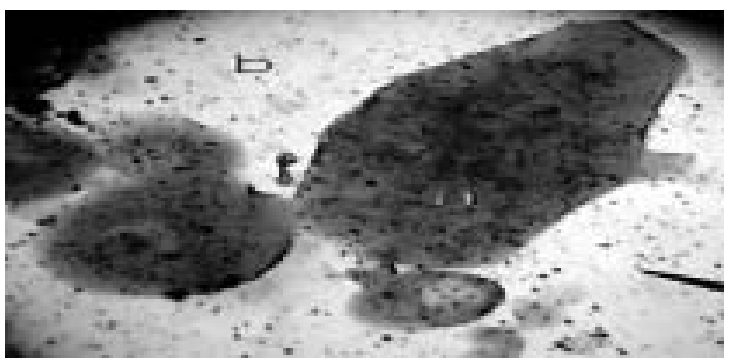

(a) Epitel vesika urinaria: (b) $P$. mirabilis

Gambar 3. Uji Hambat Adhesi P. mirabilis Vesika Urinaria Kelinci dengan Dosis Protein Hemaglutinin $0 \mu \mathrm{l}$. Direkam dengan Menggunakan Fotomikroskop Olympus dengan Pembesaran 400 kali. protein tersebut dapat menghambat bakteri untuk melakukan perlekatan. Untuk lebih jelasnya indeks adhesi $P$. mirabilis pada sel epitel vesika urinaria kelinci dapat dilihat pada Tabel 3.

Perhitungan indeks adhesi pada Tabel 1 dan 3. memperlihatkan kecenderungan semakin tinggi protein

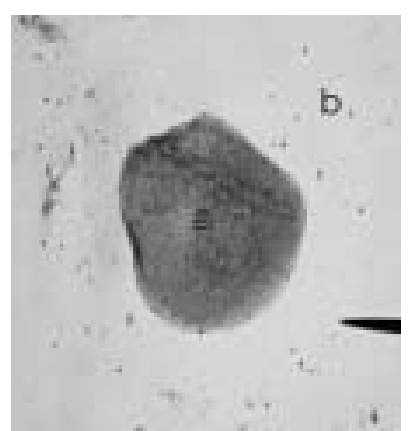

Gambar 4.a

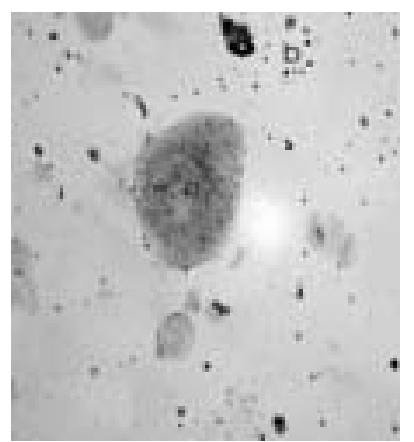

Gambar 4.c

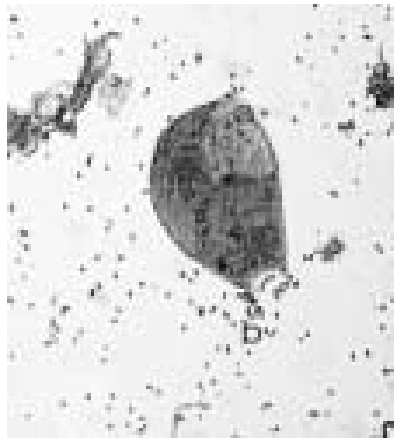

Gambar 4.e

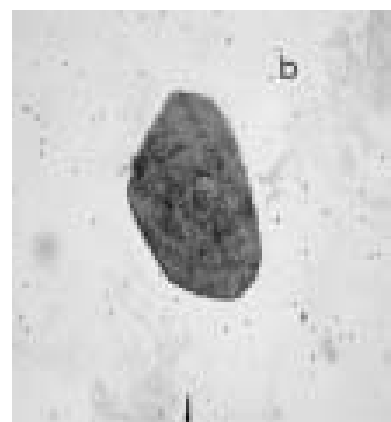

Gambar 4.b

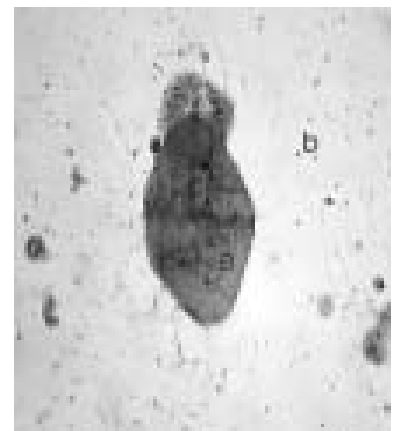

Gambar 4.d

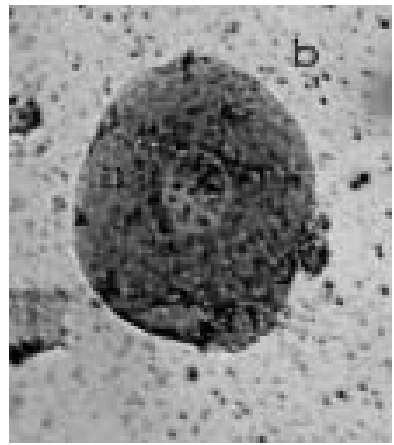

Gambar 4.f (a) Epitel vesika urinaria: (b) $P$. mirabilis

Gambar 4. a Hambat Adhesi dengan Dosis Protein $400 \mu \mathrm{l}$ Gambar 4. b Hambat Adhesi dengan Dosis Protein $200 \mu \mathrm{l}$ Gambar 4. c Hambat Adhesi dengan Dosis Protein $100 \mu \mathrm{l}$ Gambar 4. d Hambat Adhesi dengan Dosis Protein $50 \mu \mathrm{l}$ Gambar 4. e Hambat Adhesi dengan Dosis Protein $25 \mu \mathrm{l}$ Gambar 4. f Hambat Adhesi dengan Dosis Protein 12,5 $\mu \mathrm{l}$ Gambar 4.a-4.f Uji Hambat Adhesi P. mirabilis pada Vesika Urinaria Kelinci Direkam dengan Menggunakan Fotomikroskop Olympus dengan Perbesaran 1000 kali.

Tabel 2. Hasil uji hemaglutinasi OMP P. mirabilis berat molekul $35 \mathrm{kDa}$ dengan pengenceran bertingkat terhadap berbagai jenis eritosit

\begin{tabular}{|c|c|c|c|c|c|c|c|c|c|c|}
\hline \multirow{2}{*}{ Sampel eritrosit } & \multicolumn{10}{|c|}{ Pengenceran } \\
\hline & $1 x$ & $2 x$ & $3 x$ & $4 x$ & $5 x$ & $6 x$ & $7 x$ & $8 x$ & $9 x$ & $10 x$ \\
\hline Mencit & + & + & + & + & + & + & + & + & + & - \\
\hline Kelinci & + & + & - & - & - & - & - & - & - & - \\
\hline Manusia O & + & + & - & - & - & - & - & - & - & - \\
\hline Manusia A & + & - & - & - & - & - & - & - & - & - \\
\hline Manusia B & + & + & - & - & - & - & - & - & - & - \\
\hline ManusiaAB & + & + & + & - & - & - & - & - & - & - \\
\hline
\end{tabular}


dan dialisis, sehingga diperoleh protein larutan. Dari hasil elektroelusi dan dialisis OMP tersebut dilakukan uji hemaglutinin yang disalut, semakin sedikit perlekatan bakteri pada sel epitel vesika urinaria. Analisis statistik pada penelitian ini dilakukan dengan menggunakan regresi linier pada perhitungan indeks adhesi $P$. mirabilis pada sel epitel vesika urinaria tampak bahwa besarnya dosis mempengaruhi indeks adhesi $P$. mirabilis pada sel epitel vesika urinaria seperti yang ditampilkan pada Gambar 5, Tabel 4, Tabel 5 .

Berdasarkan regresi linier, tampak bahwa terdapat hubungan yang signifikan antara $P$. mirabilis protein OMP dengan bobot $35 \mathrm{kDa}$ dengan epitel vesika urinaria kelinci dengan $R$ square 0,980 . Yang artinya $98 \%$ dosis protein mempengaruhi indeks adhesi.

Proteus mirabilis termasuk dalam family Enterobacteriaceae, dalam proses awal terjadinya penyakit melalui proses adesi yang diperankan oleh fimbria maupun OMP. Keberhasilan terjadinya infeksi sangat terpengaruh oleh kemampuan melakukan adhesi. Pada penelitian ini dilakukan uji adhesi terhadap OMP. Langkah awal penelitian yaitu melakukan kultur Proteus mirabilis pada media bifasik TCG-BHI dengan tujuan untuk menumbuhkan fimbria bakteri secara optimal. Setelah itu dilakukan pemotongan fimbria secara bertingkat, sampai supernatant potongan fimbria mempunyai kekeruhan yang sama dengan PBS diberi

Tabel 3. Hasil perhitungan indeks adhesi $P$. mirabilis pada epitelvesika urinaria kelinci dengan menggunakan protein hemaglutinin dengan berat molekul $35 \mathrm{kDa}$.

\begin{tabular}{crrrrrrr}
\hline & \multicolumn{7}{c}{ Indeks adhesi } \\
\cline { 2 - 8 } Ulangan & $400 \mu \mathrm{l}$ & $200 \mu \mathrm{l}$ & $100 \mu \mathrm{l}$ & $50 \mu \mathrm{l}$ & $25 \mu \mathrm{l}$ & $12.5 \mu \mathrm{l}$ & $0 \mu \mathrm{l}$ \\
\hline I & 182 & 280 & 435 & 630 & 748 & 820 & 1084 \\
II & 176 & 340 & 460 & 590 & 724 & 860 & 1076 \\
III & 190 & 325 & 420 & 615 & 694 & 910 & 1180 \\
\hline
\end{tabular}

Tabel 4. Model summary regresi linier

\begin{tabular}{ccccc}
\hline Model & $\mathrm{R}$ & R Square & $\begin{array}{c}\text { Adjusted R } \\
\text { Square }\end{array}$ & $\begin{array}{c}\text { Std. Error } \\
\text { of the Estimate }\end{array}$ \\
\hline 1 &, 990 (a) &, 980 &, 979 & 44,73368 \\
\hline
\end{tabular}

Tabel 5. Coefficients regresi linier sederhana
NOG untuk mengelupas OMP. Hasil OMP dilakukan uji hemaglutinasi terhadap sel darah merah. Pada tahap ini dilakukan uji hemaglutinasi dengan menggunakan sel darah merah kelinci. Dari uji hemaglutinasi diperoleh hasil, OMP P. mirabilis mampu menghemaglutinasi sel darah merah sampai pengenceran 7x. Langkah selanjutnya adalah mengetahui berat molekul yang terkandung dalam OMP. Untuk mengetahui protein yang terdapat didalam OMP dilakukan SDS-PAGE. Berdasarkan hasil SDS-PAGE, pada Gambar 1, dapat dilihat OMP P. mirabilis mengandung protein dominan dengan berat molekul $45 \mathrm{kDa}, 35 \mathrm{kDa}, 23 \mathrm{kDa}$, dan $20 \mathrm{kDa}$.

Berdasar uji hemaglutinasi subunit OMP diperoleh hasil, protein subunit dengan berat molekul $35 \mathrm{kDa}$ mampu menghemaglutinasi sel darah merah mencit sampai dengan pengenceran 9x, kelinci sampai dengan pengenceran 2x. Kemampuan OMP menggumpalkan sel darah merah ada dua tipe, yaitu manosa resisten (MRHA) dan manosa sensitive hemaglutinasi (MSHA). MRHA akan berubah menjadi MSHA apabila sel darah merah diberi asam tanat $0,01 \%$. Protein hemaglutinin bakteri dapat berasal dari fimbria dan atau OMP. Struktur bakteri yang berperan dalam pelekatan adalah pili atau fimbria yang tersusun dari protein yang disebut pilin (fimbrial-adhesin) atau afimbrial adhesion yaitu suatu protein yang terdapat pada permukaan sel bakteri (Salyer \& Whitt 2002). Adhesin pada beberapa bakteri berupa protein yang dapat mengaglutinasi eritrosit yang dikenal sebagai protein hemaglutinin (Nagayama et al., 1995).

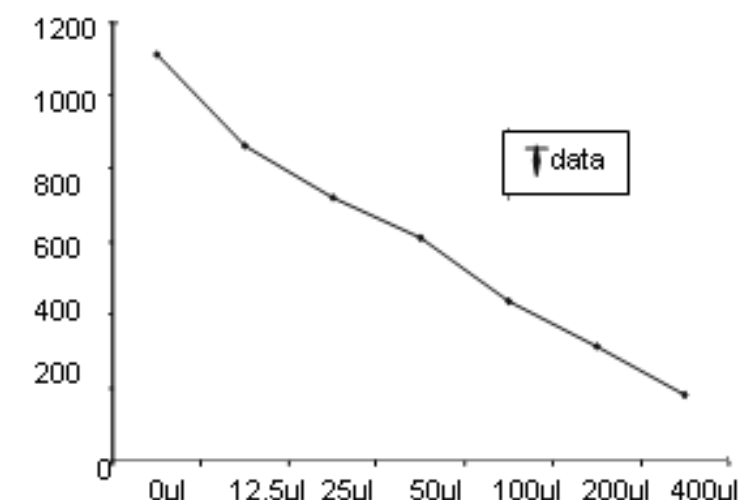

Gambar 5. Diagram Indeks Adhesi $P$. mirabilis pada Sel Epitel Vesika Urinaria Kelinci dengan Menggunakan Protein Hemaglutinin $35 \mathrm{kDa}$.

\begin{tabular}{|c|c|c|c|c|c|c|c|}
\hline \multirow{2}{*}{ Model } & \multicolumn{4}{|c|}{ Unstandardized Coefficients } & \multirow{2}{*}{$\begin{array}{c}\text { Standardized Coefficients } \\
\text { Beta }\end{array}$} & \multirow[t]{2}{*}{$\mathrm{t}$} & \multirow[t]{2}{*}{ Sig. } \\
\hline & & $\mathrm{B}$ & & Std. Error & & & \\
\hline 1 & (Constan) & & 10,571 & 21,828 & & ,484 & ,634 \\
\hline & Titer protein & & 149,012 & 4,881 & ,990 & 30,530 & ,000 \\
\hline
\end{tabular}

Pada tabel di atas menggambarkan persamaan regresi :y $=10,571+(149,012) x$ Dimana : $y$ $=$ Indeks protein, $\mathrm{x}=$ titer protein 
Kemampuan protein hemaglutinin mengaglutinasi sel darah merah hewan dan manusia tidak sama (Winarsih et al., 1997; Sanarto 2002). Pada penelitian ini didapatkan variasi tersebut, OMP $35 \mathrm{kDa}$ mampu menghemaglutinasi sel darah merah kelinci dan mencit. Data tersebut menunjukkan bahwa aktivitas hemaglutinasi bakteri $P$. mirabilis berbeda dengan bakteri yang lain. Aktivitas hemaglutinasi Campylobacter pylori terhadap eritrosit mencit, kelinci, marmot, domba, kuda, dan manusia menghasilkan reaksi yang positif (Nakazawa et al., 1989). Acinobacter mempunyai protein fimbria F16 mampu menghemaglutinasi eritrosit mencit dan manusia golongan darah $\mathrm{O}$, tetapi tidak dapat menghemaglutinasi eritrosit domba, marmot, tikus dan manusia golongan darah A, B (Noorhamdani 2005). Vibrio cholera O1 M094V memiliki protein fimbria dan OMP masing- masing dengan berat molekul $38 \mathrm{kDa}$ yang mampu mengaglutinasi eritrosit mencit, kelinci dan darah manusia golongan $O$ serta tidak mampu mengaglutinasi eritrosit marmot dan manusia golongan darah A,B, dan AB (Sumarno 2000). Bakteri Salmonella typhi memiliki protein hemaglutinin fimbria dan OMP masing-masing dengan berat molekul $36 \mathrm{kDa}$ mampu mengaglutinasi eritrosit mencit, marmot dan manusia golongan darah $\mathrm{O}$, tetapi tidak mampu mengaglutinasi eritrosit domba, manusia golongan darah $A, B$ dan $A B$ (Sanarto 2002).

Bakteri $P$. mirabilis mempunyai kemampuan mengaglutinasi eritrosit mencit, kelinci dan manusia golongan darah $\mathrm{O}$, demikian juga Acinobacter, Salmonella typhi dan Vibrio cholera O1M094V menunjukkan bahwa pada permukaan eritrosit golongan darah $\mathrm{O}$ terdapat reseptor yang komplementer dan mampu berikatan secara spesifik dengan adhesin dari berbagai jenis mikroba, khususnya bakteri Gram negatif. Karena reseptor pada permukaan eritrosit mirip dengan reseptor sel epitel hospes lainnya khususnya sel epitel yang menjadi tempat kolonisasi, maka diduga manusia golongan darah $\mathrm{O}$ pada permukaan eritrosit dan sel epitelnya mempunyai reseptor yang cocok dan komplementer dengan adhesin mikroba pathogen dibanding dengan manusia golongan darah $\mathrm{A}, \mathrm{B}$, dan $A B$, sehingga manusia dengan golongan darah $O$ lebih peka terhadap infeksi mikroba, termasuk $P$. mirabilis. Bukti tersebut didukung fakta empiric lain bahwa kejadian penyakit tukak lambung yang disebabkan oleh Helicobacter pylori meningkat pada manusia golongan darah O (Robertson et al., 2003). Selain itu manusia golongan darah O lebih peka terhadap infeksi jamur Pityrosum ovale (Shankar et al., 2002) serta infeksi virus Norwalk sering menyerang penderita golongan darah $\mathrm{O}$ dan menunjukkan terdapat suatu hubungan antara factor genetic dan resiko terkena infeksi virus Norswalk (Hutson et al., 2002). Langkah lanjut penelitian ini adalah mengidentifikasi protein adhesin, maka dilakukan uji adhesi dengan menggunakan protein hemaglutinin berat $35 \mathrm{kDa}$. Pada Gambar 2 terlihat banyak bakteri yang menempel pada sel epitel vesika urinaria kelinci dan selanjutnya pada Gambar 3, bakteri yang menempel lebih sedikit bila dibanding dengan Gambar 2. Pada Tabel 3 tampak bahwa semakin besar dosis protein hemaglutinin $35 \mathrm{kDa}$ yang disalutkan ke epitel vesika urinaria kelinci, semakin sedikit bakteri yang menempel. Hal ini disebabkan karena reseptor $P$. mirabilis pada epitel vesika uriaria kelinci sudah dijenuhi oleh OMP dengan berat molekul $35 \mathrm{kDa}$. Semakin banyak reseptor yang dijenuhi oleh protein hemaglutinin maka bakteri yang menempel semakin sedikit. Dari uji adhesi ini didapatkan hasil secara empirik bahwa protein subunit pili dengan berat molekul $35 \mathrm{kDa}$ merupakan protein adhesion. Hasil ini sesuai dengan penelitian yang dilakukan Sumarno pada Vibrio cholera O1M09V, bahwa protein hemaglutinin pili maupun OMP merupakan protein adhesion. Demikian juga pada Acinobacter baumanii protein $\mathrm{F} 16$ merupakan protein hemaglutinin yang juga berperan sebagai protein adhesion (Noorhamdani, 2005).

\section{KESIMPULAN DAN SARAN}

Telah dibuktikan bakteri $P$. mirabilis isolat dari urin penderita infeksi saluran kemih, memiliki OMP dengan berat molekul $35 \mathrm{kDa}$ yang merupakan protein hemaglutinin dan juga berperan sebagai molekul adhesin dan diyakini sebagai salah satu faktor virulensi. Meskipun masih diperlukan penelitian lebih lanjut, molekul protein heamglutinin adhesin dapat dikembangkan sebagai alat diagnostik dan kandidat vaksin dalam upaya pencegahan infeksi.

\section{UCAPAN TERIMA KASIH}

Penelitian ini dibiayai oleh DP2M Direktorat Jendral Pendidikan Tinggi, Departemen Pendidikan Nasional, Sesuai Surat Perjanjian Pelaksanaan Penelitian Hibah Bersaing Lanjutan Tahun Anggaran 2009 No: 829/ H25.3.1/PL.6/2009 tanggal 10 Januari 2009. 


\section{DAFTAR KEPUSTAKAAN}

Ehara, M. Ishibashi, M. Ichinose, Y. Iwanaga, M. Schimotori. \& S. Naito. 1986. Purification and Partial Characterisationmaf Fimbriae of Vibrio cholera 0-1; Vaccine. 5(3): 283-286.

Hutson, A.M. Atmar, R.L. Graham. \& D.Y. Ester, M.K. 2002. Norwalk Virus Infection and Disease is Assosiated with ABO HistoBlood Group Type; Infecton Disease. 185(9): 13351337.

Li Xin, Johnson. \& E.D. Mobley, TLH. 1999. Requirement of $\mathrm{MrpH}$ for Mannosa-Resistent Proteus Like fimbriae Mediated Hemaglutination by Proteus mirabilis; Infection and Immunity. 67: 2822- 2833.

Martino, P.D Bertin, Y. Girardeu, J.P. Livrelli, V. Jolly. \& B. Daefeuille-Michaud, A. 1995. Molecular Characterization and Adhesive Properties of CF29K, an Adhesin of Kleibsiella pneumonia Strain Involved in Nosocomial Infection', Infection and Immunity. 63: 4336-4344.

Mathoera, B.R Kok, J.D. Verduin, M.C. \& Nijman, M.J.R. 2002. Pathological and Therapeutic Significance of Cellular Invasion by Proteus mirabilis in Enterocystoplasty Infection Stone Model', Infection and Immunity. 70(12): 7022-7032.

Nagayama, K. Oguchi, T. Arita. \& M. Honda, T. 1995. Purification and Characterizations of a Cell-Associated Hemaglutinin of Vibrio parahaemoliticus, Infection and Immunity 63: 1987-1992.

Nakazawa T, Ishibashi M, Konishi H, Takemoto T, Shigeeda M. \& Kochiyama T.1989. Hemaglutinin Activity of Campylobacter pylori', Infection and Immunity. 57: 989-991.

Noorhamdani. 2005. Protein Fimbria 16kDa Bakteri Acinobacter baumanni dari Urin Penderita Infeksi Saluran Kemih Berperan sebagai Protein Hemaglutinin dan Adhesin', Jurnal IImu Kedokteran Brawijaya. 21(1): 44-52.

Perepelov, Ujazda E., Senchenkova N.S., Shashkov.A. \& Kaca.W. 1999. Strukctural and serological studies on the O-
Suswati, et al.

antigen of Proteus mirabilis 014, a new polysaccharide containing 2-[(R)-1-carboxyethylamino] ethyl phosphate, European Journal of Biochemistry. 261(2): 347-353.

Robertson MS, Cade J.F, Savaio H.F. \& Clancy R.L. 2003. Helicobacter pylori Infection in the Australian Activity :Current Prevalence and Lack of Assosiation with ABO Nlood Group; Intern Med J. 33(4): 163-167.

Salyer, AA. \& Whitt, DD. 2002. Bacterial Pathogenesis A Molecular Approach', ASM Press Washington DC. 115-127.

Sanarto ,S. 2002. Protein Adhesin Salmonella typhi sebagai Faktor virulensi Berpotensi Imunogenik Terhadap Produksi S-IgA Protektif; (Disertasi) Surabaya: Program Pasca Sarjana Universitas Airlangga.

Shankar, SG. Rajjith, MS. Rangananthan, S. Sivaramakharisnana, M. Natarajan, V. \& Rasool, SK. 2002. Role of Blood Groups in the Infection rate of Dandruff Caused by Pityrosporium ovale; Indian J Dermatol. 47(1): 21-23.

Smeds, A. Hemman, K. Jakava, V. Pelkonen, S. Imberechts, H. \& Palva, A. 2001. Chqaracterization of the Adhesin of Eschericiae coli F18 Fimbriae; Infection and Immunity. 69(5): 7941-7945.

Sumarno. 2000. Karakterisasi Molekuler Protein Adhesi Vibrio cholera O1M094V dan Protein Reseptornya pada Sel Epitel Usus Halus Tikua Putih (Wistar). Studi Patogenesis Vibrio cholera O1M094V. (Disertasi). Surabaya: Program Pasca Sarjana Universitas Airlangga.

Winarsih S, Sumarno. \& Roekistiningsih. 1997. Kajian Fungsi dan Sifat Immunogenitas Protein Hemaglutinin $32 \mathrm{kDa}$ dan 20 kDa pada Helicobacter pylori; Majalah Kedokteran Universitas Brawijaya. 13(2): 135-141.

Wassif, C. Cheek, D. \& Belas, R. 1995. Molecular Analysis of a Melalloprotease from Proteus mirabilis; Journal of Bacteriology. 177(20): 5790-5798. 